\title{
NARRATIVE PROCECCES AND INSTITUTIONAL ACTIVITIES: RECIPIENT GUIDED STORYTELLING IN ACADEMIC COUNSELING ENCOUNTERS ${ }^{1}$
}

\author{
Agnes Weiyun He
}

\section{Introduction}

With emphasis on the co-constructed nature of discursive practices (e.g., Jacoby \& Ochs 1995), recent research on storytelling undermines the notion of a unitary speaking ego as the source of stories. For example, C. Goodwin (1984) and M.H. Goodwin (1990) illustrated how participants co-produce situated stories, thereby organizing participation structures. Lerner (1992) documented how storytelling is assisted by participants who share knowledge of the source events for the story. Mandelbaum (1993) described how in ordinary conversations participants collaboratively shape stories in order to assign responsibilities. Ochs et al. (1989, 1992) and Miller et al. (1990) examined how children and their caregivers jointly build stories which constituted language socialization activities. However, in spite of attention paid to the role of the story recipient as an active co-teller, existing literature seems to treat the role of the recipient as that which exists and functions in the service of the teller; in other words, the recipient is assigned secondary importance to the teller in terms of both the actually telling and the purpose for which the telling is performed.

In this article, I describe a type of situation in which stories are solicited, shaped, guided by recipients who have no access to the source of the events. Specifically, the teller is asked and helped by the recipient to tell a story not out of the former's own design, but in the service of the latter's institutional objectives. I will show that this type of story narratives is contingent upon face-to-face, institutional encounters and is occasioned through a series of question-answer adjacency pairs. I will detail the sequential organization in talk-in-interaction in which such stories are embedded, re-evaluate the status of the story recipient, and locate storytelling in the context of the counseling encounter as a socialization, problem-solving, institutional activity.

The setting is an American university, which was given a pseudo-name "Central University," abbreviated as "CU." Like their counterparts in many other U.S. universities and colleges, academic counselors at CU advise their undergraduate students on academic matters such as courses, majors, General

${ }^{1}$ I thank my research assistants Shinichi Izumi and Snezha Tsoneva for help with literature search. 1 also thank Geoffrey Rayman, Phil Glenn. and the anonymous referec for helpful comments and suggestions. 
Education requirements, and graduate school or professional school preparations. They also provide routine assessments of students' degree progress. They act as both institutional gatekeepers (Erickson and Schultz 1982) and advocates of students' interests. Counseling meetings with the student are one-to-one, scheduled for halfhour intervals. An appointment slip which indicates the purpose of the student's visit, the student's name, identification number, status (e.g., freshman, sophomore), and major is given to the counselor prior to the meeting.

Despite knowledge regarding the counseling request which is stated on the appointment slip, during the actual counseling encounter, the counselor must work with the student to jointly build a shared version of the counseling problem, with its causes, developments, and consequences so as to explore possible solutions to the problem. The counseling encounter shares its character with other institutional interactions (e.g., medical encounters, therapeutic encounters) in that problems remain at the foreground of talk. Once the counseling problem is identified and solved, the mission of the meeting is achieved and closing becomes relevant (Hartford and Bardovi-Harlig 1992). Hence a significant part of the academic counseling encounter is devoted to the very activity of identifying and solving problems.

Following existing definitions of narrative (Labov 1972; Mandler 1984; Mishler 1986; Polanyi 1981, 1989), storytelling here is defined as the socially organized telling of temporally ordered events from a certain evaluative perspective. Syntactically, a story comprises at least two clauses conjoined by a temporal disjuncture (Labov 1972). Interactionally, a story episode is identified when the participants themselves exhibit orientation to the narrative nature of that episode. Structurally, a story can spread across speaking turns produced by different participants.

\section{Data}

Data presented in this article are drawn from three counseling encounters between three different counselor-student pairs. They constitute a subset of a larger data corpus collected from the academic counseling center in an American university for a related research project (He 1993), which involved eight academic counselors and twenty-one undergraduate students. These data were transcribed according to conventions developed by Gail Jefferson (Sacks et al. 1974: 731-733; also Atkinson and Heritage 1984: ix-xvi), first from the audio and then checked with the video recording. The transcription symbols used in this article can be found in Appendix A.

\section{Recipient guided storytelling}

In what follows, I examine recipient guided storytelling in academic counseling encounters by considering (1) the sequential organization of the telling in the context of formulating and identifying academic problems, (2) the status of the story recipient in light of the sequential structure and the activity type, and (3) the role of narrative questioning as a means of socializing institutional knowledge. 


\subsection{Sequential organization of recipient guided telling}

Research by conversation analysts has shown that stories are locally occasioned by moment-by-moment talk and that conversational stories are not blocks of talk, but are constructed of segments, via which the teller's talk can alternate with the recipient's (e.g., Sacks 1974). As remarked earlier, in the counseling context, talk centers around identifying and solving academic problems. This section thus focuses on the narrative formulation and identification of counseling problems across speaking turns.

\section{1.a. Framing problems}

In ordinary conversation, troubles-talk does not occur as a consecutive sequence of ordered elements but rather comprises very messy versions of the candidate sequences (Jefferson 1988). In examining institutional talk, Zimmerman (1992: 438439) suggested that narratives are employed when the problem is in some way ambiguous, has not yet transpired but may be about to. They provide more extended, chronologically organized descriptions or accounts of activities leading up to a characterization of a problem and are used to exhibit that the possibly troublesome nature of some event or activity was encountered in the course of pursuing very routine, ordinary activities.

In the case of academic counseling encounters, an institutional classification of a university student counselee's problem pre-exists to the extent that the problem is summarized on the counseling appointment slip under the category "Purpose of Visit" (e.g., "choosing a major" or "applying for re-admission"). Yet it remains to be further specified how the institutional categorization structures the actual counseling encounter and how the actual counseling encounter in turn validates or transforms the institutional categorization of the student counselee's problem.

In the following data segment, the student was enrolled the year before as an Economics major, got into academic difficulty, withdrew from the university, and is now applying for readmission. The purpose of visit stated on the appointment slip was "Applying for re-admission." "STD" stands for "subject to dismissal," a status the university assigns to students whose grade point average falls below 1.5 (on a 4.0 scale).

(1) "Applying for re-admission" (Cecilia2)

C: female; S: female.

$045 \quad(.5)((\mathrm{C}$ looks at S's file record $))$

046->C: $\quad{ }^{\circ} \mathrm{STD}^{\circ}$ ?

047 S: Yeah.

048->C: Ok. This these are probably $(.3)$ the classes?

049 S: That's last (.) yeah quarter. I got kinda

$050 \quad{ }^{\circ}(\quad)^{\circ}$

051 C: Ok:: it's Fall and Winter, ((keeps reading S' file))

052 S: Uhun, 
053 C: And then you went ' $n$ took classes at Extension.

$054 \quad((S$ nods $))$ Let's take a look at the grades.

055->C: Uh::m hhhh (.8) what happened?

056 S: What happened rhere?

057 C: $\quad$ L $^{\circ} \mathrm{Hhuh}^{\circ}$

058 S: Just had a rough time, a::nd I I just got slipped

059 through I didn't get any counseling at all and you

060 know just a little too much at one time.

061->C: Were you working?

062 S: Yeah. I: wasn't attending classes and that

063 constituted the problem hhuh=

064->C: = Hum how many hours were you working?

065 S: $\quad$ I'm a full time employee $=$

066 C: $=$ Oh:: wow::

$067 \quad(1.8)$

( $(\mathrm{C}$ suggests that $\mathrm{S}$ provides employment verification and explains what information is needed in such verification))

$095 \quad(2.2)$

096 C: What were you planning on:: as far as majors go?

097 S: Um:: reapplying in Econ major you mean?

098 C: Right.

099 S: Uhun, ((S and $\mathrm{C}$ continue discussing Econ courses $)$ )

In line $46, C$ verifies with S her STD status, which S confirms (line 47). C then verifies the exact courses for which $S$ received bad grades (line 48 ). $S$ provides the time when STD occurred ("last quarter," line 49); C recasts the time based on S's record ("Fall and Winter," line 51), with which S agrees (line 52). Next, based on S' file record, $\mathrm{C}$ narrates $\mathrm{S}$ ' consequent action ("And then you went ' $n$ took classes at Extension [an affiliated unit of CU]," line 53), which $\mathrm{S}$ again confirms (head-nod, line 54). So far, a shared story concerning the student's STD status with its associated courses, time, and consequence has been built jointly by the counselor and the student through negotiation and collaboration.

With the student's academic status being grounded, the interaction at this point could have moved on to the problem of re-admission to the university. But it did not. In line 55, $\mathrm{C}$ elicits from S an account of why STD happened. After S' brief response (lines 58-60), C elicits further details (lines 61 and 64) until she finds out that the student's STD status can be attributed to her full-time employment, a situation for which the university has made exceptions to the minimal progress requirement (i.e., students working full time can take a lighter course load). In other words, the student's present academic problem seems at this point justifiable and even pardonable in the eye of the university.

Hence we can see that the counselor, who has no prior knowledge of the student's experience (i.e., working full time, receiving no counseling) but who has expertise in the area of university rules and regulations, plays a very active part in shaping a narrative against which the student's academic problem can be grounded and justified and which in turn sets the stage for the student's counseling service request discussed later in lines 96-97. The counselor frames the story (line 46), proffers details (line 48), negotiates facts (line 51), narrates (line 53), and elicits 
elaborations (lines 55, 61 and 64). The student, while the experiencer and the primary narrator of the source events of the narrative, may or may not have knowledge regarding the specific university policies from which she may benefit. In other words, in cases like this, the teller (the student) is guided by the recipient (the counselor) through a series of question-answer adjacency pairs in terms of both the content of telling and the order in which telling is performed.

\section{1.b. Identifying problems}

On some occasions, counseling problems may emerge unexpectedly, often during a routine information-oriented degree progress assessment. The counselor may perceive something about the student's record as problematic or potentially problematic, but the student may decline to join the counselor in the construction of a problem and may even challenge the counselor's casting of problems.

Instances of this phenomenon entail that while the student does not display awareness of a problem, the counselor problematicizes the student's record or the student's response to the counselor's inquiry, thereby establishing the basis for advice giving. In this respect, the counselor's practice is very similar to that of the British health visitors described by Heritage and Sefi (1992) who use first-time mothers' replies, and particularly any indication that problems might have arisen, as a warrant for the delivery of advice.

The following extract (2) gives an example of how the counselor problematicizes a situation through eliciting a story narrative from the student and in so doing succeeds in leading the student to request advice.

(2) "Adding Business Emphasis" (Todd)

$\mathrm{T}$ : male; $\mathrm{S}$ : female.

((An "emphasis" is similar to a minor. In order to see if it is technically feasible for $S$ to add to his major a business emphasis, $T$ is reviewing $S$ 's transcripts. While doing so, he spots an F grade.))

\section{$499 \quad$ (2.)}

500->T: You had a rough quarter here, huh?

501 S: Oh ye: rah

502-> T: LWhat happened?

503 S: I I left. I didn't ta- jus I didn't take the

504 final exams.

505 T: Oh::

506 S: I I had to go home.

507-> T: What did you have to go home for?

508 S: Oh my sister was in the hospital.

509 T: Oh.

510 S: She had this thing called ( ) I

511 don't know if you're familiar with that $=$

512 T: =Uhun, $=$

513 S: =type so, (there're systems) something like that. 
514-> T: $\quad$ So you never took the finals here?

515 S: I didn- it didn't seem I could take (the )

516 T: U::m

$517 \quad$ (3.)

518-> T: I'm wondering sometimes you might be able to

519 retroactively petition (.) you seem to be you

$520 \quad$ know, $(.4)$ have ${ }_{\Gamma}$ some-

521->S: LOh I took them over. So it

522 doesn't rmean ( )

523 T: L(You know you know) So you don't care at

524 this point,

525 S: Well I mean it doesn't affect my GPA now,

526-> T: Right. (.) Where are you intending to go.after

527 you graduate from CU?

528 S: Uh I plan to work for two years to get a CPA and

529 maybe eventually go to law school.

530-> T: $\quad$ The law schools they will average the F.

531->S: They will?

532 T: Yeah.

$533 \quad$ (.)

534-> T: $\quad$ So you might want to think about that.

535->S: Ok.

Here T first categorizes S's case as "rough" (line 500), casting a negative assessment which precedes his inquiry in line 502. Later, having clarified with $\mathrm{S}$ that what led to the $\mathrm{F}$ grade was in fact a family emergency, $\mathrm{T}$ then tentatively suggests (note the use of mitigators such as "I'm wondering," "sometimes," and "might" in line 518 ) that $\mathrm{S}$ late drop the grade.

However, a complication occurs here. $\mathrm{S}$ rejects the advice in line 521. For according to the university repeat rule, the repeated grade supersedes the original grade in counting toward the grade point average; having repeated the low grade, $\mathrm{S}$ feels it is not necessary to get the $\mathrm{F}$ off his transcript. At this rejection, $\mathrm{T}$ first does a confirmation check in line 523. Then he aligns himself with the student ("Right," line 526) and proceeds with another inquiry "where are you intending to go after you graduate from CU?" (line 526). By now T has moved from the domain of S's course requirement to that of S's long-term career goals, which enables him to warn $\mathrm{S}$ of the possible negative consequences of the $\mathrm{F}$ grade (i.e., law schools do not observe the repeat rule, line 530). By line 531 when $S$ does a confirmation check ("They will?"), $\mathrm{T}$ has succeeded in orienting $\mathrm{S}$ to the potential problem. Finally, in line 534, $\mathrm{T}$ restates the advice which he first gave in line 518; this time he does so with much less hedging and more confidence.

Thus we see here a continual story-building process which culminates in establishing the counseling problem and thus advice-giving. Having elicited the family emergency story, the counselor proffers advice (lines 518-520), which is rejected by the student (line 521). The counselor subsequently uses an ad hoc, "contingent question" (Heritage and Sorjonen 1994: 7-11), which treats the student's prior response as embodying some kind of problem that needs to be dealt with, to extend the temporal frame from the past to the future (line 526) to elicit an 
alternative story about the student's long-term goals. Put in other words, the counselor's narrative inquiry topicalizes a potential problem which is confirmed by the student's response, which in turn legitimizes the subsequent delivery of advice. Eliciting and guiding the student's stories of the past and the future serves in this case as a means for collaborative reasoning in view of potential counseling problems and for socializing institutional knowledge, a point to which I will return in a later section.

\subsection{Story recipient in the counseling activity}

We have so far seen that the counselor and the student jointly author these story narratives; the counselor, as story recipient, through questioning, actively contributes to the story work of framing, eliciting, detailing, elaborating, and evaluating, thereby blurring the distinction between the role of the story teller and that of the recipient. It is thus worth re-considering the role of the story recipient in some detail, not only in the context of the sequential structure of the stories described above but also in light of the specific activities the participants are engaged in.

Levinson (1979/1992) describes activity type as "any culturally recognized activity.... a fuzzy category whose focal members are goal-defined, socially constituted, bounded, events with constraints on participants, setting, and so on, but above all on the kinds of allowable contributions" (1992: 69). He argues that particular uses and sequences of questions have to do with the overall goals of the activities in which they occur. Similarly, M. Goodwin (1990) shows that the structure and internal organization of a story are shaped by the way in which its telling is embedded within larger activities. We have seen that, in the academic counseling activity in general and counseling narrative activity in particular, questions by counselors play a crucial role. The function of a question by the counselor lies not only in its first pair part position in that it projects a relevant next turn, but also in its sequential position in relation to prior and subsequent questions.

For example, in data extracts (1) and (2), the counselors begin with global questions which topicalize the students' academic problems (e.g., an STD status, an $F$ grade) and proceed with questions regarding specific dimensions of the events which lead to the problems (e.g., full time employment, family medical emergency). The sequence of questions serves as a means of emplotment to elicit a story meaningful to the university institution and to hopefully shape an argument in favor of the student counselee. The particular role of the question is established by reference to the strategies we assume the counselors are deploying by virtue of their institutional role in the counseling activity and of their understanding of the counseling encounter as a problem-solving activity.

This point can perhaps be made more transparent with data extract (3), which illustrates a more "passive" counselor who is not constantly asking questions but which shows that, even in the seemingly passive role of listening to the student's storytelling, the counselor is an active, agenda-based story recipient, ready to (re)direct the shape of the telling so that the story can fit in some type of problemsolution institutional frame.

$$
\text { "choosing a major" (Joe1) }
$$


$\mathrm{J}$ : male; S: female

\begin{tabular}{|c|c|c|}
\hline 004 & $\mathrm{~J}:$ & Now what can I do for you? \\
\hline 005 & S: & $(($ smile $))$ \\
\hline 006 & S: & Ok:: I'm still confused \\
\hline 007 & & $(.3)$ \\
\hline 008 & $\mathrm{~J}:$ & About a major $=$ \\
\hline 009 & S: & $=$ about a major. \\
\hline $010->\mathrm{J}$ & & Good. Show me your confusion. \\
\hline 011 & S: & Ok well, when I first came to the school, I:: had \\
\hline 012 & & no idea what to major in, like most people, \\
\hline $013->\mathrm{J}$ & & Uhuh \\
\hline 014 & S: & So I undeclared. I started to take some classes \\
\hline 015 & & and thought (.5) well maybe Spanish literature is \\
\hline 016 & & the route. \\
\hline $017->$ & & $(.3)$ \\
\hline 018 & S: & So I've been taking classes on that route, $(.2)$ \\
\hline 019 & & and I'm not happy doing that $>>$ and I can't see \\
\hline 020 & & myself really $<<$ finishing out $(.8)$ my career here \\
\hline 021 & & (.3) in that major. \\
\hline $022->$ & & $(.9)$ \\
\hline 023 & S: & So I've been- I've- along the way I took some (.) \\
\hline 024 & & general education courses, (.2) a:nd (.) history \\
\hline 025 & & (.4) seems to be more exact for me. \\
\hline $\begin{array}{l}026->\mathrm{J} \\
027\end{array}$ & & $\begin{array}{l}\text { Wonderful. So you've discovered a possible major } \\
\text { ( }) \text { that's that's really good. }\end{array}$ \\
\hline 028 & S: & L yeah I like it. \\
\hline $\begin{array}{l}029->\mathrm{J} \\
030\end{array}$ & & $\begin{array}{l}\text { hhh Ok, and so (.) what do you want to know in } \\
\text { order to (really) make up your mind for a history }\end{array}$ \\
\hline 031 & & major, $($.$) or decide ($.$) uh whether you like some$ \\
\hline 032 & & other major? What can I do for you on this? \\
\hline 033 & S: & Oh like first of all, I'd like to know how many of \\
\hline 034 & & the units that I've taken $>>$ and I mean are the- $<<$ \\
\hline 035 & & is that going to count? What is it going to count \\
\hline 036 & & towards? \\
\hline & & $((S$ continues and then $\mathrm{J}$ provides info $))$ \\
\hline
\end{tabular}

Here, in response to J's elicitation (line 4), S announces her "confused" (line 6) state of mind, forecasting some order of problem. J here contributes to the construction of a problem-preface by displaying his awareness of the problem in general terms ("About a major," line 8), which serves as a collaborative completion of S's turn in line 6 and to which S readily agrees (line 9). J thus licenses S to detail her problem by acknowledging and reiterating the frame of "confusion" (line 10). A story narrative by $\mathrm{S}$ ensues (line $11 \mathrm{ff}$ ), encouraged by $\mathrm{J}$ through his continuers (line 13 ) and silences (lines 17, 22). Yet until line 28 there has been no "trouble" in the story. Hence in lines $29-32$, J probes for a problem. $\mathrm{S}$ then specifies her concerns in line $33 \mathrm{ff}$.

Note that the counselor is not merely a passive recipient of problem stories. 
Rather, he actively co-constructs the formulation of the problem through jointly framing the counseling request and providing interactional spaces (via the use of continuers and silences) and takes up the responsibility of figuring out the upshot of the student's story narrative. He attends to the student's story with a particular institutional, problem-solving agenda. When problems are absent in the story, the counselor solicits further telling in search for them.

To sum up, the active role counselors play in listening to and co-building problem-related stories emerges in part from the specific institutional activities associated with academic counseling and the role identities of the counselor. Academic counselors are story recipients of a particular kind: They, much like other professional and social service providers (e.g., doctors, psychiatrists, therapists, 911 emergency call operators), do not have prior access to the chronology of events which lead to their clients' request for service, but nonetheless play a guiding role in the course of the client's narration of problems, thus enabling guided participation in the institutional activities for the clients. In this sense, this type of guidance largely accomplished through asking questions can also be seen as a socialization activity.

\subsection{Narrative questioning as a means of socializing knowledge}

The academic counseling encounter involves asymmetries of power in the sense that the participants have varying degrees of access to valued information such as university rules and requirements (He 1994; He and Keating 1991). The encounter can thus be conceived of as a locus for the counselor and the student to socialize knowledge regarding not only rules and requirements of the university but also strategies to maximize academic success and social mobility as a result of choice of courses and choice of major.

Earlier research (Keenan [Ochs], Schieffelin and Platt 1978) indicated that question-answer pairs play a special role in the ontogeny of verbal interaction. Sacks (1992 passim) showed elegantly the role of question-answer in adult discourse. Recent research on apprenticeship (Rogoff 1990), situated learning (Chaiklen \& Lave 1993; Lave \& Wenger 1991), and language socialization (Ochs 1988) indicated that cognitive skills (e.g., modes of reasoning) develop in part as an outcome of routine interactions with other members in situated activities.

In the case of academic counseling encounters, counselors' expert knowledge is achieved, recognized and appreciated only through dialectic discourse with students. Through questions and the sequencing of questions, counselors impart and organize institutional knowledge. Students learn from counselors what questions to ask, what information is relevant, what is important, and how much information is adequate when choosing a course or a major and when coping with the university institution, a learning process which is in part construed by sharing, building narratives. In other words, storytelling guided by counselors' questions functions as a medium for the formulation and socialization of expert knowledge in this particular institutional setting. 


\section{Conclusion}

This article has focussed on some emergent and yet routine characteristics of a type of storytelling in academic counseling encounters which is guided by counselors' questions. It extends existing research on conversational stories by specifying a particular manner in which the story recipient acts as a "co-author" (Duranti 1986). It shows that question-answer adjacency pairs serve as conversational structural resources for building stories in the context of carrying out counseling activities and socializing institutional knowledge.

Further research is necessary to systematically investigate (1) how recipient guided storytelling as described in this article brings together the teller and the recipient, the individual's personal experience and the institution's mandates; (2) whether this type of storytelling is a characteristic practice for other institutional settings; and (3) how it narrativizes institutional encounters in general.

\section{References}

Atkinson, J. Maxwell and John Heritage (eds.) (1984) Structures of social action: Studies in conversation analysis. Cambridge: Cambridge University Press.

Chaiklin, Seth and Jean Lave (eds.) (1993) Understanding practice: Perspectives on activity and context. Cambridge: Cambridge University Press.

Duranti, Alessandro (1986) The audience as co-author: An introduction. Text 6.3: 239-247.

Erickson, Fredrick and Jeffrey Shultz (1982) The counselor as gatekeeper: Social interaction in interiews. New York: Academic Press.

Goodwin, Charles (1984) Notes on story structure and the organization of participation. In J. Maxwell Atkinson and John Heritage (eds.), Structures of social action. Cambridge: Cambridge University Press, pp.225-246.

Goodwin, Marjorie Harness (1990) Tactical uses of stories: Participation frameworks within girls' and boys' disputes. Discourse Processes 13: 33-71.

Hartford, Beverly S. and Kathleen Bardovi-Harlig (1992) Closing the conversation: Evidence from the academic advising session. Discourse Processes 15: 93-116.

He, Agnes Weiyun (1994) Withholding academic advice: Institutional context and discourse practice. Discourse Processes 18.3: 297-316.

He, Agnes Weiyun (1993) Reconstructing institutions through talk: A discourse study of academic counseling encounters. Ph.D. dissertation, UCLA.

He, Agnes Weiyun and Elizabeth Keating (1991) Counselor and student at talk: A case study. Issues in Applied Linguistics 2.2: 183-209.

Heritage, John and Sue Sefi (1992) Dilemmas of advice: Aspects of the delivery and reception of advice in interaction between health visitors and first time mothers. In Paul Drew and John Heritage (eds.), Talk at work. Cambridge: Cambridge University Press, pp.359-417. 
Heritage, John and Marja-Leena Sorjonen (1994) Constituting and maintaining activities across sequences: And-prefacing as a feature of question design. Language in Society 23.1: 1-29.

Jacoby, Sally and Elinor Ochs (eds.), (1995) Co-construction. A special issue of Research on Language and Social Interaction 28(.3).

Jefferson, Gail (1988) On the sequential organization of troubles talk in ordinary conversation. Social Problems .35.4: 418-441.

Keenan, Elinor Ochs, Bambi Schieffelin and Marth Platt (1978) Questions of immediate concern. In E.N. Goody (ed.), Questions and politeness. Cambridge: Cambridge University Press, pp. 44-55.

Labov, William (1972) Language in the inner city. Philadelphia: University of Pennsylvania Press.

Lave, Jean and E. Wenger (1991) Situated learning: Legitimate peripheral participation. Cambridge: Cambridge University Press.

Lerner. Gene H. (1992) Assisted storytelling: Deploying shared knowledge as a practical matter. Qualitative Sociology 15.3: 247-271.

Levinson, Stephen (1979) Activity types and language. Linguistics 17.5/6: 365-399. [Reprinted in Paul Drew and John Heritage (eds.), Talk at work. Cambridge: Cambridge University Press, 1992]

Mandelbaum, Jenny (1993) Assigning responsibility in conversational storytelling: The interactional construction of reality. Text 13.2: 247-265.

Mandler, J.M. (1984) Stories, scripts and scenes: Aspects of schema theory. Hillsdale, NJ: Lawrence Erlbaum Associates.

Miller, Peggy, R. Potts. H. Fung, L. Hoogstra and J. Mintz (1990) Narrative practices and the social construction of self in childhood. American Ethnologist 17: 292-309.

Mishler, Eliot G. (1986) Research interviewing: Context and narrative. Cambridge, MASS: Harvard University Press.

Ochs, Elinor (1988) Culture and language development: Language acquisition and language socialization in a Samoan village. Cambridge: Cambridge University Press.

Ochs, Elinor, Smith, Ruth, and Taylor, Carolyn (1989) Detective stories at dinnertime: Problemsolving through co-narration. Cultural Dynamics 2: 238-257.

Ochs, Elinor, Carolyn Taylor, Dina Rudolph and Ruth Smith (1992) Storytelling as a theory-building activity. Discourse Processes 15.1: 37-72.

Polanyi, L. (1981) What stories can tell us about their teller's world. Poetics Today 2: 97-112.

Polanyi, L. (1989) Telling the American story. Cambridge, MA: MIT Press.

Rogoff, Barbara (1990) Apprenticeship in thinking: Cognitive development in social context. New York: Oxford University Press.

Sacks. Harvey (1974) An analysis of the course of a joke's telling in conversation. In Richard Bauman and Joel Sherzer (cds.), Explorations in the ethnography of speaking. Cambridge: Cambridge University Press, pp.337-353. 
Sacks, Harvey (1992) Lectures 1 \& 2, Fall 1968. In Harvey Sacks, Lectures on conversation, Vol. 2 , 3-31. Cambridge: Blackwell Publishers.

Sacks, Harvey, Emanuel A. Schegloff and Gail Jefferson (1974) A simplest systematics for the organization of turn-taking for conversation. Language 50: 696-735.

Zimmerman, Don H. (1992) The interactional organization of calls for emergency assistance. In Paul Drew and John Heritage (eds.), Talk at work. Cambridge: Cambridge University Press, pp. 418-469.

\section{Appendix A: Transcription Symbols}

CAPS emphasis, signalled by pitch or volume falling intonation

falling-rising intonation

quiet speech

[ ] overlapped talk

cut-off

$=\quad$ latched talk

: $\quad$ prolonged sound or syllable

$(0.0)$ silences in seconds and tenths of seconds

(.) short, untimed pauses of one tenth of a second or less

( ) undecipherable or doubtful hearing

$\rightarrow \quad \operatorname{turn}(\mathrm{s})$ focused for analysis

(( )) additional observation

$\mathrm{S}$ : at the beginning of a stretch of talk, identifies the speaker; $\mathrm{S}$ is for student, other letters are for counselor

$><$ rapid speech

Joe1 extract is from the encounter between the counselor "Joe" and his first student 